\title{
PRODUKCJA WOLOWINY W POLSCE ORAZ CZYNNIKI DETERMINUJĄCE JEJ OPŁACALNOŚĆ
}

\author{
Aldona Skarżyńska \\ Instytut Ekonomiki Rolnictwa i Gospodarki Żywnościowej \\ -Państwowy Instytut Badawczy w Warszawie \\ Dyrektor Instytutu: prof. dr hab. Andrzej Kowalski
}

\begin{abstract}
Słowa kluczowe: żywiec wołowy, koszty, opłacalność produkcji, zużycie pasz
Key words: beef cattle, costs, profitability of production, feed consumption
\end{abstract}

\begin{abstract}
S y n o p s i s. Celem badań była ocena wyników ekonomicznych produkcji żywca wołowego oraz identyfikacja głównych czynników determinujących jej opłacalność. Wyniki produkcji żywca analizowano w trzech grupach gospodarstw, wydzielonych według kwartyli nadwyżki bezpośredniej, tj. w gospodarstwach najlepszych, średnich i najsłabszych. Analizie poddano średnie trzyletnie. Głównym czynnikiem różnicującym efekty ekonomiczne produkcji żywca wołowego były poniesione koszty, wpływ ceny sprzedaży był mniejszy. Decydujący wpływ miały koszty bezpośrednie, które w kolejnych grupach gospodarstw sukcesywnie rosły: w średnich gospodarstwach były wyższe niż w najlepszych o 40,2\%, a w najsłabszych - o 82,0\%. Wysokość kosztów bezpośrednich była determinowana głównie przez koszt wymiany stada, wpływ miał także koszt pasz. Produkcja żywca wołowego ekonomicznie efektywna była tylko w gospodarstwach najlepszych, wskaźnik opłacalności wynosił $111,9 \%$, natomiast w średnich i najsłabszych koszty produkcji zostały pokryte częściowo, odpowiednio w 88,8 i $72,4 \%$.
\end{abstract}

\section{WSTĘP}

W Polsce w strukturze towarowej produkcji rolniczej udział żywca wołowego (bez cieląt) sukcesywnie zwiększa się, w 2005 roku wynosił 5,1\%, w 2010 roku - 5,4\%, a w 2015 roku $-7,0 \%$. Natomiast w towarowej produkcji zwierzęcej w tych samych latach stanowił: 8,3, 9,6 i 12,0\% [GUS 2016b]. Produkowana wołowina w zdecydowanej większości pochodzi od zwierząt ze stad mlecznych. Co prawda znaczny odsetek krów ras mlecznych (około 15\%) jest zacielany nasieniem buhajów ras mięsnych, jednak większość tych mieszańców (jako cielęta lub młode bydło) do dalszego opasu wywożono za granicę [Litwińczuk, Grodzki 2014].

Chów bydła opasowego jest alternatywą dla produkcji mleka. Dotyczy to szczególnie gospodarstw posiadających znaczący areał użytków zielonych i ziemi słabo zagospodarowanej, czasami leżącej odłogiem. Rolnicy, którzy utrzymywali bydło mleczne i nie sprostali konkurencji, powinni zainteresować się tym kierunkiem produkcji, aby wykorzystać wolne pomieszczenia i rezerwy paszowe powstałe w wyniku ograniczenia chowu bydła mlecznego [Nogalski, Wroński 2011]. Przy produkcji żywca wołowego z założenia powinno się 
wykorzystywać systemy niskonakładowe, tj. naturalne użytki zielone i pasze objętościowe przy ograniczonych dawkach pasz treściwych [Wójcik 2011]. Sposób żywienia zwierząt jest bardzo ważny w kontekście konsumenckich wymagań w stosunku do wołowiny, w zasadzie wymuszają one stosowanie odpowiedniej technologii opasu bydła rzeźnego.

W ostatnich latach zwiększa się liczba zwolenników produkcji wołowiny tzw. systemem półintensywnym, czyli z wykorzystaniem pasz z trwałych użytków zielonych i zapewnieniu dobrostanu zwierzętom. Badania wykonane w wielu ośrodkach naukowych (w tym w Polsce) wskazują, że wołowina $\mathrm{z}$ takich systemów produkcji zawiera więcej składników prozdrowotnych, tj. frakcji tłuszczowej, składników mineralnych i antyoksydantów [Litwińczuk, Grodzki 2014].

System produkcji jest ważny ze względów ekonomicznych. Sytuacja rynkowa (niskie spożycie wołowiny i jej wysoka cena, niewygórowane ceny skupu bydła rzeźnego) zmusza producentów do obniżania kosztów produkcji przy jednoczesnym podnoszeniu jakości wytwarzanego surowca. Producent, dążąc do sprostania wymaganiom rynku, a jednocześnie do poprawy opłacalności żywca wołowego, powinien zwrócić uwagę m.in. na organizację bazy paszowej, racjonalną organizację stada oraz optymalizację przebiegu procesu opasania. Według Henryka Grodzkiego, główne czynniki hamujące rozwój sektora produkcji wołowiny w Polsce to mała opłacalność produkcji oraz duże rozdrobnienie stad i zróżnicowanie systemów opasu powodujące niewyrównaną jakość tusz i mięsa [Grodzki 2013].

Celem badań była ocena wyników ekonomicznych i efektywności produkcji żywca wołowego oraz identyfikacja głównych czynników determinujących jej opłacalność.

\section{MATERIAŁ I METODA BADAŃ}

W badaniach wykorzystano dane dotyczące produkcji bydła opasowego zebrane i przetworzone w systemie AGROKOSZTY ${ }^{1}$, natomiast dane o gospodarstwach, w których te badania przeprowadzono, pochodziły z bazy polskiego FADN. Próbę badawczą stanowiły gospodarstwa indywidualne położone na terenie całego kraju, które utrzymywały bydło opasowe. Liczba gospodarstw w próbie badawczej wynosiła: w 2009 roku - 52, w 2012 roku -85 , a w 2014 roku -86.

W celu identyfikacji czynników różnicujących ekonomiczne wyniki chowu bydła gospodarstwa z próby badawczej pogrupowano według wzrastającego poziomu nadwyżki bezpośredniej uzyskanej ze 100 kg brutto żywca wołowego. Nadwyżka jest pierwszą kategorią dochodową w rachunku kosztów i stanowi różnicę między wartością produkcji a kosztami bezpośrednimi. Pozwala na uproszczoną ocenę ekonomicznej efektywności

Badania rolniczych działalności produkcyjnych w systemie AGROKOSZTY prowadzone są w indywidualnych gospodarstwach rolnych wybieranych celowo z próby reprezentatywnej, która znajduje się w polu obserwacji polskiego FADN. Takie podejście jest stosowane, aby była możliwość uzupełniania baz danych systemu AGROKOSZTY danymi pochodzącymi z polskiego FADN. Dobór gospodarstw do badań każdej działalności dokonywany jest niezależnie. Warunkiem doboru jest prowadzenie wybranej do badań działalności i określona skala jej produkcji. Gospodarstwa uczestniczące w badaniach położone są na terenie całego kraju, nie stanowią jednak - ze względu na sposób doboru - próby reprezentatywnej dla gospodarstw indywidualnych w Polsce prowadzących określoną działalność. Prowadzone badania są w pełni dobrowolne i zawsze wymagają zgody rolnika. W systemie AGROKOSZTY gromadzone są ilościowe i wartościowe dane o poziomie produkcji, poniesionych nakładach i kosztach bezpośrednich w odniesieniu do działalności produkcji roślinnej i zwierzęcej. Dane te zbierane są według jednolitych założeń z precyzyjnie wyznaczonymi standardami i dokładnie określoną metodyką. Pozwalają one na obliczenie nadwyżki bezpośredniej. 
wytwarzania wołowiny w zależności od wydajności poszczególnych zwierząt, zmian cen jej sprzedaży oraz zmian cen środków produkcji. Wyniki produkcji żywca wołowego poddano analizie w trzech grupach gospodarstw wydzielonych według kwartyli nadwyżki bezpośredniej [Ziętara 1995], tzn.:

- w gospodarstwach najlepszych - pierwszy kwartyl (tj. 25\% górnych wyników badanej zbiorowości gospodarstw),

- w gospodarstwach średnich - drugi i trzeci kwartyl (tj. 50\% środkowych wyników badanej zbiorowości gospodarstw),

- w gospodarstwach najsłabszych - czwarty kwartyl (tj. 25\% dolnych wyników badanej zbiorowości gospodarstw).

Metoda podziału i prezentacji wyników według kwartyli jest znana i powszechnie stosowana w badaniach ekonomicznych. Kwartyl jako parametr statystyczny stosowany jest do wyznaczenia rozkładu normalnego analizowanej zmiennej w badanej populacji. Umożliwia podział zbiorowości na cztery części ze względu na wartość tej zmiennej.

W celu pokazania zmian w wynikach analizowano średnie trzyletnie. Ujęcie takie niweluje wpływ przypadkowych wahań możliwych przy analizie średnich jednorocznych (np. wskutek zmian warunków rynkowych). Uzyskane wyniki jako średnie dla wyodrębnionych grup gospodarstw przedstawiono w układzie tabelarycznym. W ocenie wyników wykorzystano analizę poziomą, porównując parametry charakteryzujące produkcję żywca wołowego w poszczególnych grupach gospodarstw.

Badaniami objęto przychody, czyli wartość produkcji potencjalnie towarowej (wielkość sprzedaży jest równa wielkości produkcji), wybrane nakłady, koszty ogółem (bezpośrednie i pośrednie ${ }^{2}$ ) oraz efekty ekonomiczne. Za podstawowy miernik oceny uzyskanych efektów przyjęto poziom nadwyżki bezpośredniej i dochodu z działalności (wartość produkcji pomniejszona o koszty ogółem). W obliczeniach nie uwzględniono wsparcia dopłatami. Do oceny efektywności wykorzystania poniesionych nakładów zastosowano wskaźniki:

- relacja nadwyżki bezpośredniej do wartości produkcji-pokazuje techniczno-produkcyjną efektywność w procesie produkcji żywca wołowego,

- relacja wartości produkcji do kosztów ogółem, tj. bezpośrednich i pośrednich łącznie (wskaźnik opłacalności) - pokazuje ekonomiczną efektywność produkcji.

Dla zrealizowania celu badań korzystano także z opracowań statystyki polskiej.

2 Koszty bezpośrednie produkcji zwierzęcej obejmują: koszt zwierząt wchodzących do stada w ramach jego wymiany, koszt pasz, leczenia i ubezpieczenia zwierząt, czynszów dzierżawnych za użytkowanie powierzchni paszowej do 1 roku, oraz koszty specjalistyczne, tzn. mające bezpośredni związek z daną działalnością oraz podnoszące jakość i wartość produktu finalnego. Składniki kosztów pochodzące z zewnątrz gospodarstwa wyceniane są według cen zakupu, a wytworzone we własnym gospodarstwie - według cen sprzedaży loco gospodarstwo (np. pasze z produktów towarowych). Wyjątkiem są pasze własne z produktów nietowarowych (np. kiszonka z kukurydzy), które wyceniane są według kosztów bezpośrednich poniesionych na ich wytworzenie.

Koszty pośrednie obejmują: (1) koszty ogólnogospodarcze - energia elektryczna, opał, paliwo napędowe, remonty bieżące i konserwacje, usługi, ubezpieczenia budynków, majątkowe i komunikacyjne, pozostałe koszty, np. opłata za telefon; (2) podatki - rolny, leśny, od działów specjalnych, od nieruchomości i inne; (3) koszt czynników zewnętrznych - koszt pracy najemnej, czynsze dzierżawne, odsetki od kredytów; (4) amortyzację produkcyjnych środków trwałych - np. budynków, maszyn, środków transportu. 


\section{WYNIKI}

W Polsce do 2005 roku utrzymywała się spadkowa tendencja w pogłowiu zwierząt zaliczanych do grupy ,pozostałe bydło”, tzn. w pogłowiu bydła niemlecznego. W 1990 roku w kraju było 5130 tys. sztuk tych zwierząt, a w 2004 roku tylko 2557 tys. sztuk - nastąpił spadek o 50,2\% [Małkowski i in. 2015]. Nie był to jednak spadek jednokierunkowy, a jego tempo było zróżnicowane. Do redukcji stada przyczyniła się niższa opłacalność produkcji wołowiny i cielęciny w porównaniu z produkcją mleka czy żywca wieprzowego. Pewien wpływ miał także mniejszy popyt na wołowinę, który obniżył się na korzyść wieprzowiny [Stańko, Lewandowski 2008]. Wejście Polski do Unii Europejskiej (UE) przyczyniło się do zahamowania tendencji spadkowych w pogłowiu bydła niemlecznego. W 2005 roku liczba zwierząt wynosiła 2687 tys. sztuk, a w 2017 roku 3769 tys. sztuk, nastąpił więc wzrost o 40,3\%. Według prognozy, w 2018 roku pogłowie bydła niemlecznego zwiększy się do 3820 tys. sztuk [Zawadzka, Pasińska 2017]. Sprzyja temu większy popyt eksportowy oraz wzrost cen wołowiny.

Dla rozwoju chowu bydła z przeznaczeniem na mięso akcesja Polski do UE była ważnym impulsem. W 2004 roku w porównaniu z rokiem 2003 cena skupu żywca wołowego wzrosła o 35,6\%, a w 2005 roku o kolejne 19,5\%. Generalnie w rozpatrywanych latach (2003-2017) cena ta zwiększała się, ale były także lata, w których zarejestrowano spadek (rys. 1.). Procesy integracji i globalizacji sprawiają, że kształtowanie się cen produktów rolnych wynika nie tylko z relacji popytowo-podażowych w kraju, ale także z sytuacji na rynkach światowych i powiązania z cenami światowymi (np. wzrost cen żywca w latach 2011-2012 wynikał ze wzrostu eksportu do Turcji i krajów arabskich), oddziaływania instrumentów wspólnej polityki rolnej czy jest wynikiem jeszcze innych uwarunkowań.

W Polsce nie ma tradycji chowu bydła ras mięsnych, dlatego produkcja wołowiny w większości powiązana jest z mlecznym kierunkiem użytkowania bydła. Kierunek użytkowania bydła zależy od odsetka krów mlecznych lub krów mamek w ogólnym pogłowiu krów. Krowy mamki i krowy mleczne różnią się cechami fizjologicznymi oraz wynikającą stąd predyspozycją do określonego kierunku produkcji. Na wydajność zarówno o użytkowaniu mlecznym, jak i mięsnym decydujący wpływ mają czynniki genetyczne (rasowe)

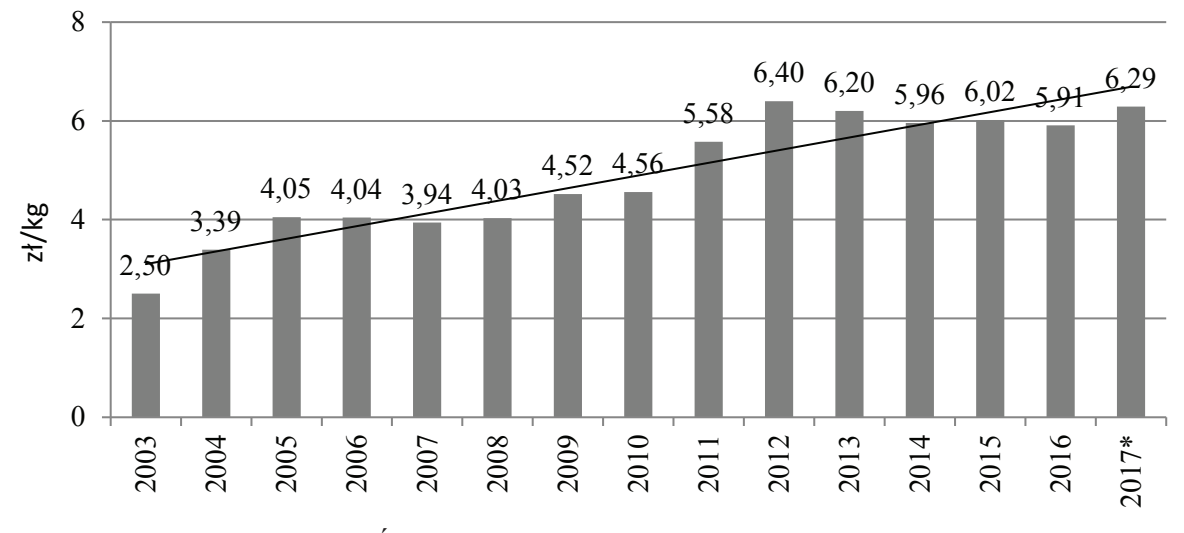

* Średnia cena skupu w okresie I-X 2017 r.

Rysunek 1. Ceny skupu żywca wołowego w Polsce w latach 2003-2017 Źródło: opracowanie własne na podstawie: [GUS 2009, GUS 2016a, GUS 2017a]. 
i pozagenetyczne (żywienie). W literaturze przedmiotu określa się, że 25-procentowy udział krów mlecznych i 75-procentowy udział krów mamek świadczy o użytkowaniu dwukierunkowym. Więcej niż 75\% krów mamek w stadzie świadczy o użytkowaniu mięsnym, a mniej niż 25\% krów mamek - o użytkowaniu bydła w kierunku mlecznym [Peters 2008]. Z danych GUS [GUS 2017b] wynika, że w Polsce według stanu na czerwiec 2016 roku w pogłowiu krów ogółem udział krów mamek wynosił tylko 8,0\%.

Dane prezentowane na rysunku 2. pokazują, że produkcja żywca wołowego w Polsce wzrosła $\mathrm{w}$ ostatnich kilkunastu latach. W porównaniu $\mathrm{z}$ okresem przedakcesyjnym (tj. 2003 r.), w 2014 roku była wyższa o 36,0\%, a w latach 2015 i 2017 odpowiednio o 55,3 i $77,8 \%$. Należy jednak zauważyć, że wyższa produkcja w latach 2015-2017 w dużej mierze wynikała z likwidacji stad krów mlecznych w wielu gospodarstwach.

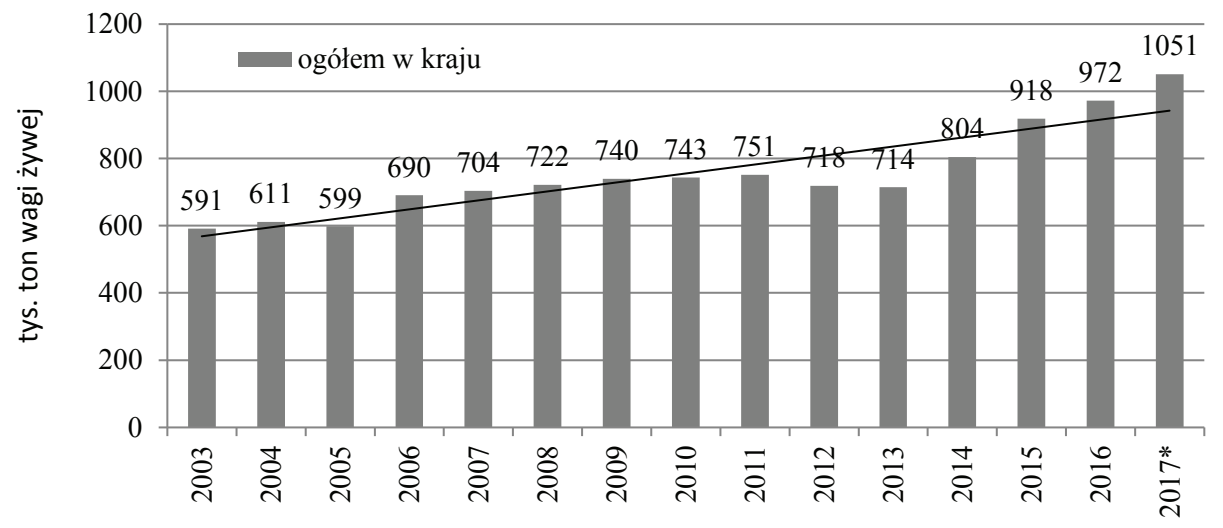

Rysunek 2. Produkcja żywca wołowego (bez cielęcego)** w Polsce w latach 2003-2017

Źródło: opracowanie własne na podstawie [GUS 2004, Zawadzka, Pasińska 2017].

* Prognoza IERiGZ-PIB,

** produkcja krajowa $=$ ubój przemysłowy + ubój w gospodarstwie + eksport żywych zwierząt import żywych zwierząt [Zawadzka, Pasińska 2017].

Głównym celem każdego rolnika prowadzącego chów bydła opasowego jest wysoka opłacalność produkowanej wołowiny. W ogólnym ujęciu opłacalność opasu bydła zależy od czynników zewnętrznych, na które producenci mają ograniczony wpływ (np. regulacje prawne dotyczące sektora wołowiny, popyt i podaż na rynku wołowiny), oraz od czynników wewnętrznych, które w dużym stopniu zależą od rolników; najważniejsze z nich to potencjał wytwórczy (czyli zasoby ziemi, pracy i kapitału, ich jakość oraz sposób wykorzystania) oraz wewnętrzna organizacja gospodarstwa.

Zarządzając procesem produkcji, producenci powinni kierować się rachunkiem ekonomicznym. Analiza ekonomicznej efektywności produkcji pozwala na ocenę wyników w przeszłości, ale także na kalkulację wyników w przyszłości. Pozwala także na rozpoznanie „słabych” i „mocnych stron” procesu produkcji, a tym samym na identyfikację czynników, których siła oddziaływania na opłacalność żywca wołowego jest znacząca. Taka wiedza pomaga wyeliminować zagrożenia, a jednocześnie przyczyni się do poprawy wyników.

W Polsce producenci bydła najczęściej rozliczają się za dostarczenie na rzeź żywych zwierząt. W tym systemie kwota, którą uzyska producent, zależy od kategorii bydła, wagi 
zwierząt i wartości rzeźnej określanej na żywym zwierzęciu. Pierwszą czynnością przy takim skupie bydła jest zaliczenie go do jednej z sześciu kategorii w zależności od płci i wieku zwierząt. Ten podział w skupie jest dostosowany do klasyfikacji poubojowej w systemie EUROP ${ }^{3}$ [Wajda, Burczyk 2013].

W celu identyfikacji czynników różnicujących wyniki żywca wołowego analizie poddano średnie trzyletnie, takie przedstawienie wyników niweluje wpływ przypadkowych wahań możliwych przy analizie średnich jednorocznych oraz pozwala z większą pewnością określić kierunek zmian. W próbie badawczej liczba gospodarstw skalsyfikowanych jako najlepsze i najsłabsze wynosiła po 56 w każdej z grup, natomiast gospodarstw średnich było 111. Średnia powierzchnia użytków rolnych (UR) w wydzielonych grupach była zbliżona, zawierała się w przedziale 48,84-55,05 ha, a udział trwałych użytków zielonych w UR stanowił od 19,2\% w jednostkach najlepszych do $26,6 \% \mathrm{w}$ średnich i najsłabszych - tabela 1 .

Według literatury, przeciętna waga ubijanego bydła sukcesywnie zwiększa się i w coraz większym stopniu wpływa na wielkość produkcji żywca wołowego. W Polsce około $90 \%$ pogłowia bydła stanowi rasa holsztyńsko-fryzyjska (HF) odmiany czarno-białej. W opinii specjalistów, niższa wartość tusz tej rasy bydła wynika z kierowania do uboju sztuk o zbyt niskiej wadze. Opasanie buhajków HF do 600-700 kg masy ciała zwiększa wydajność poubojową i poprawia parametry rzeźne tuszy, co ma wpływ na cenę [Rycombel i in. 2012, Grodzki 2013].

Wyniki badań wskazują, że zarówno najwyższą wagę sprzedawanych zwierząt, jak i cenę żywca zanotowano w najlepszych gospodarstwach. W dwóch kolejnych grupach gospodarstw, tj. średnich i najsłabszych, obserwowano jednokierunkowy spadek obu zmiennych. W porównaniu do najlepszych gospodarstw waga zwierząt sprzedawanych $\mathrm{w}$ średnich gospodarstwach była niższa o 3,4\% (tj. $21 \mathrm{~kg}$ ), a w najsłabszych o 8,2\% (tj. o 50 $\mathrm{kg}$ ), natomiast cena sprzedaży żywca była niższa odpowiednio o 2,1\% (tj. o $0,13 \mathrm{zl}$ ) i 7,9\% (tj. o 0,49 zł). Można przypuszczać, że producenci w gospodarstwach sklasyfikowanych jako najlepsze, znając zasady klasyfikacji żywca, dostosowali do tych wymagań sposób opasu bydła i w efekcie uzyskali wyższą cenę za dostarczone do uboju bydło rzeźne. Cena sprzedaży żywca wołowego jest jednym z czynników determinujących opłacalność jego produkcji. Wyniki badań są spójne z doniesieniami innych badaczy i wskazują na jej współzależność z wagą sprzedawanych zwierząt.

Przeprowadzone badania pozwoliły zidentyfikować kilka czynników, które różnicują wyniki ekonomiczne produkcji żywca wołowego. Ważnym czynnikiem jest udział produkcji netto (przyrostu) w produkcji brutto żywca wołowego. Z badań wynika, że udział przyrostu w produkcji brutto w kolejnych grupach gospodarstw - wraz ze spadkiem nadwyżki bezpośredniej - zmniejszał się, w najlepszych gospodarstwach wynosił 71,2\%, średnich $-54,1 \%$, a w najsłabszych $-49,0 \%$. Jednocześnie produkcja brutto wołowiny przypadająca na $1 \mathrm{~kg}$ przyrostu zwiększała się: w najlepszych gospodarstwach było to 1,40 $\mathrm{kg}$, średnich $-1,85 \mathrm{~kg}$, a w najsłabszych $-2,04 \mathrm{~kg}$. Wynika to głównie z faktu, że do stada $\mathrm{w}$ ramach jego wymiany, wprowadzono zwierzęta o relatywnie dużej wadze. W porównaniu z najlepszymi gospodarstwami, średnia waga 1 sztuki bydła wprowadzonej do stada (w przeliczeniu na $100 \mathrm{~kg}$ żywca brutto) była większa w średnich gospodarstwach o $67 \mathrm{~kg}$ (tj. o 32,2\%), a w najsłabszych gospodarstwach o $74 \mathrm{~kg}$ (tj. o 35,4\%).

Ocena tusz w systemie EUROP została wprowadzona w celu zagwarantowania producentom żywca wołowego wynagrodzenia adekwatnego do jakości uzyskanej tuszy. Rozliczenie według tego systemu obejmuje z roku na rok coraz większy odsetek bydła poddanego ubojowi przemysłowemu [Wnęk i in. 2016]. 
Tabela 1. Wybrane informacje o gospodarstwach i wyniki produkcji żywca wołowego w grupach gospodarstw, średnio w latach badań

\begin{tabular}{|c|c|c|c|c|}
\hline \multirow[t]{2}{*}{ Wyszczególnienie } & \multirow[t]{2}{*}{ Jedn. } & \multicolumn{3}{|c|}{$\begin{array}{c}\text { Grupy gospodarstw - kwartyle nadwyżki } \\
\text { bezpośredniej }\end{array}$} \\
\hline & & $\begin{array}{l}25 \% \text { gosp. } \\
\text { najlepszych }\end{array}$ & $\begin{array}{l}50 \% \text { gosp. } \\
\text { średnich }\end{array}$ & $\begin{array}{l}25 \% \text { gosp. } \\
\text { najsłabszych }\end{array}$ \\
\hline Liczba gospodarstw w badaniach & & 56 & 111 & 56 \\
\hline Powierzchnia użytków rolnych (UR) & [ha/gosp.] & 50,02 & 48,84 & 55,05 \\
\hline $\begin{array}{l}\text { Udział trwałych użytków } \\
\text { zielonych w UR }\end{array}$ & {$[\%]$} & 19,2 & 26,6 & 26,6 \\
\hline Produkcja żywca netto (przyrosta ${ }^{\mathrm{a}}$ & [dt/gosp.] & 34,98 & 49,13 & 31,41 \\
\hline Produkcja żywca brutto ${ }^{\mathrm{b}}$ & [dt/gosp.] & 49,12 & 90,81 & 64,06 \\
\hline $\begin{array}{l}\text { Udział produkcji netto w produkcji } \\
\text { brutto żywca }\end{array}$ & {$[\%]$} & 71,2 & 54,1 & 49,0 \\
\hline Waga sprzedawanych zwierząt & [kg/szt.] & 613 & 592 & 563 \\
\hline Cena sprzedaży żywca wołowego & {$[\mathrm{z} \mathfrak{z} / \mathrm{kg}]$} & 6,21 & 6,08 & 5,72 \\
\hline \multicolumn{5}{|c|}{ Na $100 \mathrm{~kg}$ żywca brutto } \\
\hline Wartość produkcji (WP) & {$[\mathrm{zl}]$} & 621 & 608 & 572 \\
\hline Koszty bezpośrednie ogółem & {$[\mathrm{zl}]$} & 311 & 436 & 566 \\
\hline z tego: wymiana stada ${ }^{c}$ & & 170 & 288 & 369 \\
\hline pasze z zakupu & & 41 & 31 & 53 \\
\hline pasze własne towarowe & & 74 & 86 & 101 \\
\hline pasze własne nietowarowe & & 19 & 23 & 33 \\
\hline pozostałe & & 7 & 7 & 11 \\
\hline Nadwyżka bezpośrednia & {$[\mathrm{zt}]$} & 310 & 173 & 6 \\
\hline Koszty pośrednie ogółem & {$[\mathrm{z} 1]$} & 244 & 249 & 224 \\
\hline z tego: koszty pośrednie rzeczywiste & & 124 & 119 & 108 \\
\hline amortyzacja & & 93 & 109 & 87 \\
\hline koszt czynników zewnętrznych & & 28 & 21 & 30 \\
\hline Dochód z działalności & {$[\mathrm{zl}]$} & 66 & -77 & -218 \\
\hline Koszty ogółem (KO) & {$[\mathrm{zl}]$} & 555 & 685 & 790 \\
\hline $\begin{array}{l}\text { Relacja nadwyżki bezpośredniej do } \\
\text { wartości produkcji }\end{array}$ & {$[\%]$} & 49,9 & 28,4 & 1,1 \\
\hline Wskaźnik opłacalności (WP/KO) & {$[\%]$} & 111,9 & 88,8 & 72,4 \\
\hline
\end{tabular}

${ }^{a}$ Produkcja żywca netto to roczny przyrost wagowy uzyskany w stadzie bydła opasowego $\mathrm{w}$ wieku powyżej 1 roku.

b Produkcja żywca brutto to produkcja netto powiększona o wagę zwierząt z zakupu.

${ }^{\mathrm{C}} \mathrm{W}$ ramach wymiany do stada mogą być wprowadzane cielęta do opasu w wieku 1 roku oraz zwierzęta powyżej 1 roku z innych grup bydła.

Źródło: opracowanie na podstawie badań własnych. 
Cena zwierząt wprowadzonych do stada w wydzielonych grupach gospodarstw także była różna. W porównaniu do najlepszych gospodarstw średnia cena (zł/kg) bydła wprowadzonego do stada w ramach jego wymiany była wyższa w średnich gospodarstwach o 0,23 zł (tj. o 28,4\%), a w gospodarstwach najsłabszych o 0,49 zł (tj. o 60,5\%). Konsekwencją tych uwarunkowań były relatywnie wysokie koszty wymiany stada w grupie gospodarstw średnich i najsłabszych. W porównaniu z gospodarstwami sklasyfikowanymi jako najlepsze w przeliczeniu na $100 \mathrm{~kg}$ żywca były one wyższe odpowiednio o 69,4\% i 117,1\%.

Analiza sytuacji dochodowej produkcji żywca wołowego w gospodarstwach najlepszych, średnich i najsłabszych wykazała, że głównym czynnikiem różnicującym efekty ekonomiczne są koszty produkcji. W najlepszych gospodarstwach, w porównaniu do średnich, koszty ogółem (łącznie bezpośrednie i pośrednie) poniesione na wyprodukowanie $100 \mathrm{~kg}$ żywca brutto były niższe o 19,0\%, a w porównaniu z najsłabszymi - o 29,8\%. Zadecydowały o tym wyłącznie koszty bezpośrednie, których poziom w porównaniu z gospodarstwami średnimi był niższy o $28,7 \%$, a w odniesieniu do najsłabszych o $45,1 \%$. Niższe koszty w najlepszych gospodarstwach to efekt niższego kosztu wymiany stada oraz odmiennego sposobu żywienia zwierząt, który miał wpływ na koszt pasz. Natomiast koszty pośrednie w wydzielonych grupach gospodarstw kształtowały się na podobnym poziomie, w przedziale 224-249 zł. Siła oddziaływania tego agregatu kosztów na zróżnicowanie wyników była więc znikoma.

Analizując strukturę pasz treściwych w dawce żywieniowej zwierząt w kolejnych grupach gospodarstw stwierdzono malejący udział pasz treściwych z zakupu, a rosnący pasz własnych z produktów towarowych. Oznacza to, że sposób opasu bydła w najlepszych gospodarstwach wiązał się z większym udziałem w dawce pasz treściwych z zakupu, w porównaniu z gospodarstwami średnimi udział ten był większy o 4,2 p.p., a z najsłabszymi o 5,8 p.p. (większy udział nie oznaczał większego zużycia). We wszystkich grupach gospodarstw w strukturze pasz treściwych z zakupu przeważały koncentraty i mieszanki przemysłowe, stanowiły one od 47,8 do $57,2 \%$ (tab. 2.).

Tabela 2. Struktura i zużycie pasz na $100 \mathrm{~kg}$ przyrostu żywca wołowego w grupach gospodarstw, średnio w latach badań

\begin{tabular}{cccc}
\hline Wyszczególnienie & \multicolumn{3}{c}{$\begin{array}{c}\text { Grupy gospodarstw - kwartyle nadwyżki } \\
\text { bezpośredniej bez dopłat }\end{array}$} \\
\cline { 2 - 4 } & $\begin{array}{c}25 \% \text { gosp. } \\
\text { najlepszych }\end{array}$ & $\begin{array}{c}50 \% \text { gosp. } \\
\text { średnich }\end{array}$ & $\begin{array}{r}25 \% \text { gosp. } \\
\text { najsłabszych }\end{array}$ \\
\hline Pasze treściwe [\%] & 100,0 & 100,0 & 100,0 \\
z tego: pasze treściwe z zakupu & 17,1 & 12,9 & 11,3 \\
z tego: koncentraty i mieszanki & 56,0 & 47,8 & 57,2 \\
ziarna i śruty ze zbóż & 11,9 & 15,5 & 15,0 \\
pozostałe pasze treściwe & 32,1 & 36,7 & 27,8 \\
pasze treściwe własne & 82,9 & 87,1 & 88,7 \\
w tym: ziarna i śruty ze zbóż & 99,3 & 98,4 & 97,2 \\
\hline \multicolumn{1}{c}{ Zużycie pasz na 100 kg przyrostu } \\
Treściwe [dt] & 1,98 & 3,07 & \\
Zielonka [dt] & 3,31 & 2,97 & 5,94 \\
Siano i słoma [dt] & 1,22 & 1,18 & 2,57 \\
Kiszonka i sianokiszonka [dt] & 8,81 & 12,48 & 14,30 \\
\hline
\end{tabular}

Źródło: opracowanie na podstawie badań własnych. 
Zużycie pasz na 100 kg przyrostu żywca obrazuje efektywność żywienia bydła. Dane zawarte w tabeli 2. pokazują, że w najlepszych gospodarstwach system żywienia był najbardziej efektywny. Zużycie pasz treściwych oraz kiszonek i sianokiszonek było najmniejsze, podczas gdy w pozostałych grupach gospodarstw było znacznie większe. Porównując skrajne grupy, należy stwierdzić, że w najlepszych gospodarstwach zużycie pasz treściwych było mniejsze o 49,7\%, a kiszonek i sianokiszonek o 38,4\% niż w najsłabszych. Zużycie pasz objętościowych suchych i zielonki w gospodarstwach najlepszych i średnich było podobne i mniejsze niż w gospodarstwach najsłabszych. Potencjał genetyczny bydła wymusza na producentach wołowiny dążenie nie tylko do optymalizacji potrzeb pokarmowych na podstawowe składniki odżywcze, ale również na witaminy i składniki mineralne. W badanych gospodarstwach ilość skarmionych dodatków mineralnych i paszowych łącznie, jaka przypadała na $100 \mathrm{~kg}$ przyrostu, wynosiła od 1,94 kg w grupie najlepszych do $3,50 \mathrm{~kg}$ w najsłabszych.

Ocenia się, że struktura ilościowa pasz w dawce żywieniowej zwierząt mogła mieć związek z rodzajem opasu bydła w poszczególnych gospodarstwach. Według Jana Szarka, wyróżnia się opas intensywny, półintensywny i ekstensywny [Szarek 2012]. Ich dobór zależy od bazy paszowej w gospodarstwie, powierzchni upraw oraz dostępności pastwisk. Różnią się one sposobem żywienia zwierząt, zużyciem składników pokarmowych na 1 kg przyrostu, wysokością dziennych przyrostów masy ciała, długością cyklu opasu oraz wskaźnikami ekonomicznymi, np. opłacalnością opasu. Z opracowań innych badaczy wynika, że żywienie zwierząt w znaczącym stopniu (w 65-70\%) decyduje o efektywności opasu bydła [Litwińczuk i in. 2013].

W wydzielonych grupach gospodarstw nadwyżka bezpośrednia z produkcji żywca wołowego została zrealizowana, jej wysokość była jednak bardzo zróżnicowana. W gospodarstwach najlepszych produkcja $100 \mathrm{~kg}$ żywca wołowego zapewniła nadwyżkę w wysokości 310 zł, w średnich 173 zł, a w najsłabszych zaledwie 6 zł. Na poziomie dochodu produkcja żywca wołowego w gospodarstwach średnich i najsłabszych przyniosła stratę, odpowiednio 77 i 218 zł/100 kg żywca. Dochód uzyskali tylko producenci wołowiny w najlepszych gospodarstwach, było to $66 \mathrm{zz} / 100 \mathrm{~kg}$ żywca (tab. 1).

Do oceny efektywności produkcji żywca wołowego w badanych gospodarstwach zastosowano dwa wskaźniki. Relacja nadwyżki bezpośredniej do wartości produkcji obrazuje techniczno-produkcyjną efektywność produkcji żywca wołowego. Wyniki obliczeń wskazują, że w gospodarstwach średnich i najsłabszych produkcja żywca była technicznie nieefektywna, udział nadwyżki w wartości produkcji był bardzo niski, wynosił odpowiednio 28,4 i 1,1\%. W najlepszych gospodarstwach relacja ta była korzystniejsza, wynosiła 49,9\%, nie przekroczyła jednak akceptowalnej granicy 60\% [Soliwoda 2014].

Miarą oceny efektywności ekonomicznej był wskaźnik opłacalności, którego wyrazem jest relacja wartości produkcji do kosztów ogółem. Z punktu widzenia gospodarstwa efektywność ekonomiczna jest bardzo ważna, zapewnia możliwość przetrwania na rynku, co jest warunkiem dalszego rozwoju. Wyniki wskazują, że ekonomicznie efektywna była tylko produkcja żywca wołowego w najlepszych gospodarstwach, wskaźnik opłacalności wynosił $111,9 \%$. W gospodarstwach średnich i najsłabszych rolnicy ponieśli stratę (odpowiednio 77 i 218 zł na $100 \mathrm{~kg}$ żywca). Średnio w tych grupach gospodarstw produkcja żywca była ekonomicznie nieefektywna, co wynikało z nieefektywności technicznej. Dla pełnego pokrycia poniesionych kosztów (ogółem) cena sprzedaży żywca musiałaby przewyższać rzeczywistą cenę jego sprzedaży w gospodarstwach średnich o $12,7 \%$, a w najsłabszych o $38,1 \%$.

Określony poziom opłacalności produkowanej wołowiny może być czynnikiem stymulującym lub ograniczającym skalę jej produkcji. Dążąc do wyższej opłacalności, należy przede wszystkim brać pod uwagę poniesione koszty. Cena sprzedaży wołowiny też jest ważna, 
ale w jej przypadku rolnicy nie mają zbyt dużych możliwości manewru, dlatego poprawy opłacalności powinni przede wszystkim poszukiwać w ograniczaniu kosztów. Ich wysokość zależy od wielkości stada i dostępu do użytków zielonych oraz racjonalnego sposobu żywienia zwierząt. Koszty znacząco obniża stosowanie pasz z własnej produkcji, ważna jest też jakość pasz objętościowych oraz wiedza o tym, jaki udział w dawce żywieniowej zwierząt powinny stanowić pasze objętościowe, a jaki - treściwe. Liczniejsze stado sprzyja minimalizacji kosztów, na co wpływa między innymi fakt, że koszty funkcjonowania całego gospodarstwa rozkładają się na większą liczbę jednostek, przez co stają się mniej odczuwalne dla rolników.

Ukierunkowanie produkcyjne, czyli produkcja na większą skalę, zwykle wiąże się z bardziej racjonalnym wyposażeniem gospodarstw w środki trwałe. Jest to ważne zagadnienie, ponieważ właściwy dobór maszyn i urządzeń rolniczych oraz dostosowanie budynków i budowli do potrzeb gospodarstwa ma wpływ na wyniki ekonomiczne. Koszty ich utrzymania należą bowiem do kategorii kosztów niezależnych od rozmiarów prowadzonej produkcji i stanowią poważne obciążenie dla każdego gospodarstwa. Niepełne wykorzystanie posiadanych zasobów powoduje wyższe koszty prowadzonej produkcji. Jeżeli nie będzie im odpowiadał dostatecznie wysoki poziom wartości produkcji (przychodów), wzrośnie jej kosztochłonność. Skutkiem może być pogorszenie ekonomicznej efektywności wytwarzania. W tej sytuacji zagrożeniem jest ryzyko materialne, czyli niebezpieczeństwo poniesienia straty. W produkcji rolniczej ryzyko ma szczególny charakter, powodem jest duża liczba zagrożeń i nieprzewidywalność pewnych zjawisk. Dodatkowo zmiana podjętych wcześniej decyzji jest najczęściej utrudniona ze względu na długi cykl produkcji.

Wzrost skali produkcji wołowiny na ogół stymuluje spadek kosztów i zwykle jest to zmiana jednokierunkowa, podczas gdy cena sprzedaży żywca nie zawsze zmienia się jednokierunkowo. Mimo to niższe koszty determinują wzrost nadwyżki bezpośredniej oraz wzrost opłacalności wyrażonej jako procentowa relacja przychodów do kosztów. Większa skala produkcji żywca wołowego sprzyja także spadkowi pracochłonności produkcji, co oznacza, że siła robocza wykorzystywana jest bardziej efektywnie. Z badań wynika, że warunkiem uzyskania dochodu z produkcji żywca wołowego jest jej prowadzenie na odpowiednio dużą skalę, określona technologia i poziom intensywności produkcji, ale także racjonalne zarządzanie i efektywne wykorzystanie posiadanych środków trwałych [Skarżyńska, Jabłoński 2015].

W opinii ekspertów, na wzrost skali produkcji wołowiny negatywnie oddziałuje mała opłacalność produkcji i niskie jej spożycie, brak integracji producentów żywca wołowego z przemysłem mięsnym, organizacja skupu prowadzona przez pośredników, a nie przez przemysł mięsny oraz mała aktywność producentów w zakresie tworzenia grup producenckich [Grodzki 2013].

\section{WNIOSKI}

Badania dotyczące opłacalności produkcji żywca wołowego przeprowadzono w gospodarstwach ekonomicznie silniejszych, które mają większą szansę rozwoju. Wyniki nie wyczerpują w pełni zagadnień związanych z kształtowaniem się kosztów i dochodów z opasu bydła rzeźnego jako działalności powiązanej z chowem krów mlecznych, dają jednak wiarygodny obraz sytuacji w wydzielonych grupach gospodarstw i pozwalają na sformułowanie wniosków o charakterze poznawczym. 
1. Stwierdzono współzależność między wagą sprzedawanych zwierząt a ceną żywca. W najlepszych gospodarstwach waga zwierząt i cena ich sprzedaży były najwyższe. $\mathrm{W}$ dwóch kolejnych grupach gospodarstw, tj. średnich i najsłabszych, obie zmienne charakteryzował jednokierunkowy spadek.

2. Głównym czynnikiem różnicującym efekty ekonomiczne z produkcji żywca wołowego były poniesione koszty, wpływ ceny sprzedaży był mniejszy. Porównując obie zmienne w skrajnych grupach gospodarstw, tj. najlepszych i najsłabszych, zróżnicowanie ceny sprzedaży $1 \mathrm{~kg}$ żywca było 1,1 razy, a kosztu produkcji 1,4 razy.

3. Decydujący wpływ na wysokość dochodu z produkcji żywca wołowego miały koszty bezpośrednie. W kolejnych grupach gospodarstw, czyli wraz ze spadkiem nadwyżki bezpośredniej, koszty te sukcesywnie rosły. W gospodarstwach średnich były wyższe o $40,2 \%$, a w najsłabszych - o $82,0 \%$ niż w najlepszych.

4. Wysokość kosztów bezpośrednich determinował koszt wymiany stada, na jego poziom wpływ miały waga i cena zwierząt wchodzących do stada. W gospodarstwach średnich i najsłabszych obie zmienne były relatywnie wysokie (wyższe niż w najlepszych). Ocenia się, że w tych jednostkach skierowano do opasu więcej zwierząt dorosłych, a tym samym o wyższej wadze, czyli powyżej 1 roku. Świadczy o tym udział przyrostu żywca (produkcji netto) w produkcji brutto, udział ten w gospodarstwach najlepszych wynosił $71,2 \%$, średnich - 54,1\%, a w najsłabszych - 49,0\%. Wyniki pokazują, że opłacalność produkcji żywca wołowego była większa, jeżeli większy był jego przyrost. Dotyczy to sytuacji, kiedy do opasu kierowane są - przynajmniej w większości - młode zwierzęta, czyli cielęta w wieku 1 roku.

5. Na wysokość kosztów bezpośrednich znaczny wpływ miał także koszt pasz. Jego wysokość zależy od struktury rodzajowej pasz w dawce żywieniowej zwierząt oraz ich zużycia. Wyniki wskazują, że w najlepszych gospodarstwach sposób żywienia był najbardziej efektywny.

6. Produkcja żywca wołowego była ekonomicznie efektywna tylko w najlepszych gospodarstwach, wskaźnik opłacalności (relacja wartości produkcji do kosztów ogółem) wynosił $111,9 \%$. Natomiast w gospodarstwach średnich i najsłabszych producenci ponieśli stratę, koszty produkcji zostały pokryte tylko częściowo, odpowiednio w 88,8 i 72,4\%. Dla zapewnienia pełnego ich pokrycia cena sprzedaży żywca - w odniesieniu do uzyskanej - musiałaby wzrosnąć w gospodarstwach średnich o 12,7\%, a w najsłabszych o 38,1\%.

7. Pomimo nienajlepszej sytuacji dochodowej chowu bydła rzeźnego są przesłanki, które wskazują, że pozycja Polski na europejskim rynku wołowiny może się umocnić. Atutem jest wykorzystywanie w żywieniu zwierząt głównie pasz objętościowych, a ograniczone stosowanie pasz treściwych.

8. Na rozwój chowu bydła w Polce stymulujący wpływ może mieć względnie stabilne funkcjonowanie rynku żywca wołowego oraz poprawa warunków cenowych. Impulsem może być także wzrost spożycia wołowiny przez polskich konsumentów.

9. Ważne dla rozwoju tego kierunku produkcji są również ścisłe powiązania producenta żywca (również tego z niewielką skalą produkcji) z odbiorcą surowca, czyli ubojnią. Korzystne byłoby także intensywniejsze włączenie się przetwórni w promocję wołowiny na rynku krajowym, propagujące np. prozdrowotne właściwości tego mięsa wynikające $z$ dominującej w Polsce technologii produkcji wołowiny opartej głównie na paszach z trwałych użytków zielonych. 


\section{LITERATURA}

Grodzki Henryk, 2013: Stan i kierunki rozwoju produkcji wołowiny w Polsce [w] Polskie gospodarstwa z chowem bydła na tle wybranych krajów, Wojciech Ziętara (red.), Monografie Programu Wieloletniego 2011-2014, IERiGŻ-PIB, nr 86, s. 168-188.

GUS, 2004: Fizyczne rozmiary produkcji zwierzęcej w 2003 r. (oraz analogiczne pozycje dla kolejnych lat, tj. 2005-2016).

GUS, 2009: Ceny $w$ gospodarce narodowej $2008 r$.

GUS, 2016a: Ceny w gospodarce narodowej w $2015 \mathrm{r}$.

GUS, 2016b: Rocznik statystyczny RP 2016.

GUS, 2017a: Biuletyn statystyczny nr 10.

GUS, 2017b: Zwierzęta gospodarskie w $2016 r$.

Litwińczuk Zygmunt, Henryk Grodzki, 2014: Stan hodowli i chowu bydła w Polsce oraz czynniki warunkujace rozwój tego sektora. „Przegląd Hodowlany”, nr 6, s. 1-5.

Litwińczuk Zygmunt, Paweł Żółkiewski, Witold Chabuz, Mariusz Florek, 2013: Przyrosty dobowe i wartość rzeźna buhajków opasanych paszami z trwałych użytków zielonych i kiszonką z kukurydzy z uwzględnieniem wartości pokarmowej skarmianych pasz. „Roczniki Naukowe Polskiego Towarzystwa Zootechnicznego", t. 9, nr 4, s. 27-35.

Małkowski Jan, Danuta Zawdzka, Dorota Pasińska, 2015: Aktualny i przewidywany stan na rynku wołowiny, „Rynek Mięsa. Stan i Perspektywy”, nr 59, s. 27-42.

Nogalski Zenon, Marek Wroński, 2011: Doskonalenie technologii opasu bydła. „Przegląd Hodowlany", nr 4, s. 17-20.

Peters Kurt J., 2008: Developments in Cattle product markets and market Prices, Humboldt Universitat zu Berlin, Institute of Animal Sciences, International Workshop, Vilnius, 22 August.

Rycombel Danuta, Danuta Zawadzka, Agnieszka Wierzbicka, 2012: Sytuacja na światowym rynku wołowiny i jej wptyw na polski sektor wołowiny, ,, Monografie Programu Wieloletniego 20112014", nr 36, s. 16, 19, 22-23, 73, 79, 87.

Skarżyńska Aldona, Konrad Jabłoński, 2015: Wyniki ekonomiczne wybranych produktów rolniczych w 2014 roku, IERiGŻ-PIB, Warszawa, s. 51-61.

Soliwoda Michał, 2014: Bezpieczeństwo finansowe gospodarstw rolniczych w Polsce z perspektywy Wspólnej Polityki Rolnej, „Wieś i Rolnictwo”, nr 3(164), s. 45-55.

Stańko Stanisław, Radosław Lewandowski, 2007: Tendencje zmian na rynku wołowiny i cielęciny w Polsce w latach 1990-2006. "Oeconomia" 6 (2), s. 71-80.

Szarek Jan, 2012: Jakie sa rodzaje opasu młodego bydła? Portal Społecznościowy Producentów Żywca Wołowego, http://www.bukaciarnia.pl/porady-eksperta/jakie-sa-rodzaje-opasu-mlodego-bydla, html?cookies=true, dostęp: 3.10.2017.

Wajda Stanisław, Ewa Burczyk, 2013: Co należy wiedzieć, gdy sprzedajemy bydło na rzeź? „Hodowca Bydła", nr 9, http://www. portalhodowcy.pl/hodowca-bydla-archiwum/153-hodowca-bydla-9-2013/1587-co-nalezy-wiedziec-gdy-sprzedajemy-bydlo-na-rzez, dostęp: 4.06.2017.

Wnęk Karolina, Karol Pawłowski, Tomasz Przysucha, 2016: Analiza zmian w ocenie i obrocie bydłem opasowym w Polsce w latach 2005-2014. „Przegląd Hodowlany”, nr 4, s. 6-9.

Wójcik Piotr, 2011: Ekonomiczne aspekty produkcji mięsa wołowego w Polsce, „Przegląd Hodowlany", nr 4, s. 20-22.

Zawadzka Danuta, Dorota Pasińska, 2017: Aktualny i przewidywany stan rynku wołowiny, „Rynek mięsa. Stan i perspektywy", Warszawa, nr 53, s. 28-43.

Ziętara Wojciech, 1995: Rachunkowość jako pomoc w zarzadzaniu gospodarstwem rolniczym, [w] Dostosowanie rachunkowości rolnej IERiGŻ do gospodarki rynkowej, Materiały z seminarium, IERiGŻ, Warszawa, s. 57-63. 


\section{Aldona Skarżyńska}

\section{BEEF PRODUCTION AND DETERMINANTS ITS PROFITABILITY IN POLAND}

\section{Summary}

The main objective of the study was to evaluate the economic performance and efficiency of bovine animals production and identify the main determinants of such production profitability. The results of the study were analyzed in three groups of farms divided by quartiles of gross margin, i.e. in the best, middle and weakest. The results were analyzed as average in three years. The main factor differentiating the economic effects from the production of beef cattle was the costs incurred, the impact of the sale price was lower. The decisive impact was direct costs, which in successive groups of farms increased, with regard to the best of farms in the medium ones were higher by $40.2 \%$ and the weakest ones - by $82.0 \%$. The level of direct costs was determined mainly by the exchange cost of the herd and also by the cost of feed. Beef cattle production was economically effectiveness only in the best farms, the profitability index was $111.9 \%$, while in the medium and weakest group of farms at 88.8 and $72.4 \%$ respectively.

Adres do korespondencji: Dr hab. Aldona Skarżyńska, prof. IERiGŻ-PIB Instytut Ekonomiki Rolnictwa i Gospodarki Żywnościowej - PIB

Zakład Rachunkowości Rolnej ul. Świętokrzyska 20, 00-950 Warszawa e-mail: aldona.skarzynska@ierigz.waw.pl 